\title{
Medida angular para aferição do tônus muscular na paralisia facial****
}

\author{
Angular measurement for determining muscle tonus in facial \\ paralysis
}

\author{
Adriana Tessitore* \\ Luis Alberto Magna** \\ Jorge Rizzato Paschoal***
}

*Fonoaudióloga. Doutoranda em Ciências Médicas pela Faculdade de Ciências Médicas da Universidade Estadual de Campinas (Unicamp). Coordenadora do Setor de Reabilitação Orofacial do Ambulatório de Paralisia Facial do Hospital de Clínicas da Unicamp. Endereço para correspondência: Rua Boaventura do Amaral, 736 - Apto. 91 - Campinas - SP - CEP 13015190

(dritessi@hotmail.com).

**Médico. Professor Titular do Departamento de Genética Médica Faculdade de Ciências Médicas Unicamp.

***Médico Otorrinolaringologista. Livre-Docente na Área de Otorrinolaringologia pela Faculdade de Ciências Médicas da Unicamp. Chefe do Ambulatório da Base do Crânio e Paralisia Facial da Disciplina de Otorrinolaringologia da Faculdade de Ciências Médicas da Unicamp.

****Trabalho Realizado no Ambulatório de Paralisia Facial do Hospital de Clínicas da Unicamp; Disciplina de Otorrinolaringologia.

Artigo Original de Pesquisa

Artigo Submetido a Avaliação por Pares

Conflito de Interesse: não

Recebido em 08.05.2009.

Revisado em 01.10.2009; 16.11.2009; 08.01.2010, 12.02.2010.

Aceito para Publicação em 22.04.2010.

\begin{abstract}
Background: the decrease of facial movements in peripheral facial paralysis and the resulting aesthetical sequels may have important emotional repercussions as a consequence to the functional deficit, and depending on the intensity of the clinical condition. Orofacial rehabilitation has as a purpose to favor the recovery of orofacial movements and to adequate and/or adapt orofacial functions and facial mimic. However, quantifying therapeutic results in an attempt to measure the muscle tonus is a challenge. Generally, the used forms of measurement are general and subjective. Aim: to propose the labial commissure angle as an anthropometric marker and to evaluate its reliability as an objective tool to evaluate the modification of the facial muscle tonus after rehabilitation. Method: participants of the study were 20 patients presenting peripheral facial paralysis - level IV. The study was conducted using images from the photographical documentation taken fifteen days to one year post-onset of facial paralysis. The angle was measured by tracings determined by pre-established anthropometric facial points, such as the line between the glabella and the gnation and the crossing with the left and right chelion points determining an angle manually measured with a protractor on the photography. Results: The average Labial Commissure Angle before treatment was of 101.70 and after rehabilitation of 93.80 (standard deviation, SD = 4.3). The statistical analysis indicated a significant difference $(\mathrm{p}<0.001)$. Conclusion: the results obtained suggest that the Labial Commissure Angle allows the objective evaluation of facial muscle tonus modification.
\end{abstract}

Key Words: Facial Paralysis; Muscular Tonus; Face; Myofunctional Therapy.

\section{Resumo}

Tema: na paralisia facial periférica, a diminuição dos movimentos faciais e as sequelas estéticas resultantes podem ter repercussões emocionais importantes consequentes ao déficit funcional, na dependência da intensidade do quadro clinico. A reabilitação orofacial visa otimizar os movimentos residuais, na paralisia incompleta, e as suas adequações e/ou adaptação às funções orofaciais e da expressividade facial. Entretanto, quantificar o resultado terapêutico é um desafio. Em geral, as graduações utilizadas são generalistas e subjetivas. Objetivo: propor o Ângulo da Comissura Labial e avaliar sua confiabilidade como recurso objetivo na avaliação da modificação do tônus da musculatura facial na evolução da paralisia facial. Método: foram estudados 20 pacientes com paralisia facial periférica - grau IV. O estudo se fez sob imagens da documentação fotográfica de pacientes com paralisia facial, tomadas a partir de quinze dias de instalação e ao final de um ano de acompanhamento clínico. Mediu-se o ângulo por meio de traçados determinados por pontos faciais antropométricos pré-estabelecidos, como a linha entre a glabella e gnation e o cruzamento com os pontos chelion direito e esquerdo, determinando um ângulo medido manualmente com um transferidor na fotografia. Resultados: a média do Ângulo da Comissura Labial foi de 101,70 nas tomadas iniciais, diminuindo para 93,80 (desvio padrão $=4,3$ ) após um ano de evolução. $O$ teste estatístico revelou diferença estatisticamente significante $(\mathrm{P}<0,001)$. Conclusão: os resultados obtidos sugerem que o Ângulo da Comissura Labial permite a avaliação objetiva da modificação do tônus da musculatura facial.

Palavras-Chave: Paralisia Facial; Tono Muscular; Face; Terapia Miofuncional. 


\section{Introduction}

The precise control of facial muscles produces subtle variations in the muscular physiology that are essential to the facial expressivity and to the functions of mastication, swallowing and speech (1). In cases of Peripheral Facial Paralysis (PFP), the facial mobility decreases and, besides the cosmetic consequences, may lead to important emotional repercussions and clear functional disorders. Disorders in muscle self-awareness and nose-lip philter deviation may interfere in the articulation of bilabial and labiodental phonemes. The decrease in intra-oral pressure produced by flaccid muscles makes the retention of liquids inside the oral cavity very difficult and produces retention of food residues in the oral vestibule on the paralyzed side (2-5). In severe cases dysphagia may occur with solid food due to the decrease in the saliva production (6-7).

The need to characterize the PFP evolution led to the development of clinical quantification methods. Subjective and objective methods have been proposed to this assessment (8). The subjective methods are based in the performance during pre-determined facial movements. Among them, the House-Brackman (HB) $(9 ; 11)$ graduation system is universally the most used. In this scale the PFP is graded in six categories: (I) normal, (II) slight deformity, (III) moderate deformity, (IV) moderately severe dysfunction, (V) severe dysfunction, (VI) total paralysis (12). The assessment of the muscle tonus is subjective and hardly quantifiable. According to the Stedman (13) medical dictionary muscle tonus refers to a continuous activity state or to a tension that surpasses the physical properties i.e,, active resistance to stretching; in skeletal muscles and depends on the efferent enervation.

Our objective is to propose the Labial Comissure Angle (LCA) as an objective resource to the assessment of the changes in the facial muscle tonus in patients with PFP.

\section{Methods}

Prospective longitudinal study conducted in the Otorhinolaringology discipline of the School of Medical Sciences - University of Campinas (Unicamp), Sao Paulo, Brazil. All subjects signed the consent form approved by the institution's ethical committee (\# 514/2003).

Twenty patients (14 male and 6 female) with ages varying between 20 and 60 years were included. Ten patients presented PFP to the right and 10 to the left. The inclusion criteria determined that the patients should have completed PFP (HB-IV) independently of the etiology, have the facial nerve (FN) anatomically preserved and PFP onset time of at least 15 days. The exclusion criteria eliminated patients with FN section, systemic conditions that could enhance the PFP severity (neurological, degenerative, endocrinological), other $\mathrm{HB}$ graduation and PFP for a long period. All the sample characterization is shown in Table 1.

All patients were clinically followed according with the service's routine during a period of 1 year.

Photographic records were used to the assessment of facial rest (tonus) according to the protocol:

Photographic record of facial rest during the first Speech and Language Pathology (SLP) session to the assessment of the LCA. Patients were photographed with the head in rest position in relation to the Frankfurt plane (parallel to the ground) in complete facial rest prior and after one year of intervention. A Canon Digital Power Shot S13 IS (6.0 megapixels) camera was used, with a tripod, with standardized environmental luminosity, without flash and with a distance of 1 meter between the lens and the patient. In the black \& white developed photos with $15 \mathrm{~cm} \times 21 \mathrm{~cm}$ the ACL were traced and measured with a protractor.

Video documentation was used to the assessment of the PFP degree including the assessment of the facial movements and graduation by the $\mathrm{HB}(9)$ scale according to the protocol: a) same distance, luminosity and position used in the photographed records; b) twice repetition of each movement: (1) Say the complete name and count from 1 to 10. (2) Upend the eyebrows and relax ("startle expression"). (3) Join the eyebrows ("annoyed expression"). (4) Blink slowly. (5) Slowly close the eyes (approximate the image). (6) Strongly close the eyes. (7) Contract nasal muscles ("bad-smell expression"). (8) Pout and relax. (9) Inflate the cheeks. (10) Smile with closed lips and relax. (11) Lower the mouth corners and relax. (12) Smile openly and relax.

Photographic measures of LCA at the beginning and after 1 year of intervention (Figures 1 and 2). Recording of the angular measures. The LCA was measured from the facial median line, determined by the line that connects the anthropometric points (14-15) glabela (most salient point between both eyebrows or between both epicanthus) and gnathion (point determined by the junction of the hemi-jaws, forming a slight dent). Transversely to this line we traced another line that connects the 
FIGURE 1. initial assessment of person with left PFP (LCA=1040).

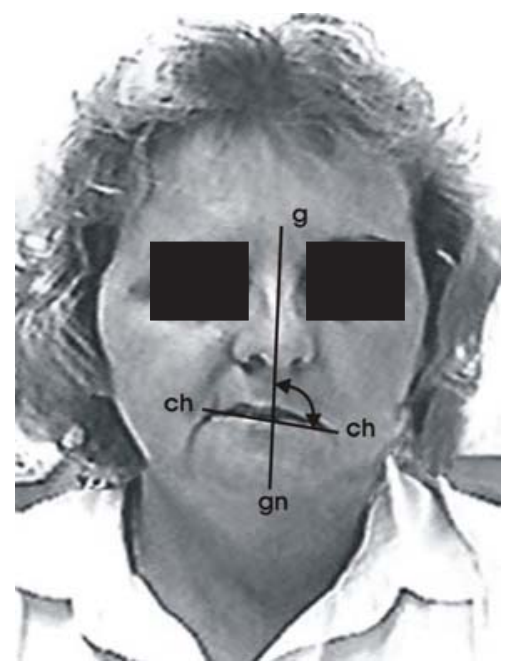

Legend: g: glabela; ch: cheilion, gn: gnathion.

FIGURE 2. final assessment of person with left PFP (LCA=92o).

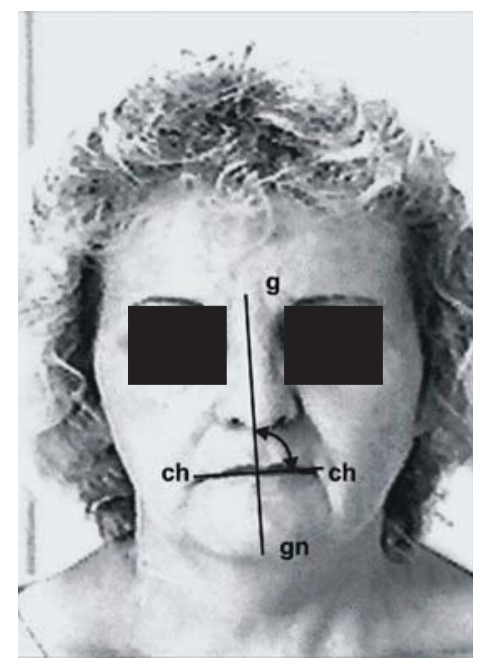

Legend: g: glabela; ch: cheilion, gn: gnathion cheilion points right and left (determined by the junction that forms the lips comissures). The glabela and gnathion points are fixed and the cheilon point of the paralyzed side is a mobile point. The crossing of these two lines forms the LCA. This measure is being suggested as a quantifying resource referring to an aspect usually described according to individual interpretation (subjectively).

Measures determined prior and after improvement (Table 1) were statistically compared with the paired t-Student test. To determine the reliability of the results obtained to the angles, three specialists performed the same measurements according to the described procedures. Each specialist worked independently oblivious to the results recorded by the others.

The reliability of the angles' degrees measured in our protocol is a continuous numeric variable and not a categorical one. The statistical procedure used to assess the inter-observer results was the Pearson's correlation coefficient: the larger the agreement between observers, the more reliable each obtained result is considered.

\section{Results}

The average age of the studied cases was 76.65 years with standard deviation (SD) of 13.50 .

The average of initial LCA was 101.7o (SD=5.6). The LCA post-treatment average was 93.80 $(\mathrm{SD}=4,4)$. Therefore the average $\mathrm{LCA}$ reduction was 7,9o (t-Student Test) $(\mathrm{P}<0,001)$.

The Pearson correlation coefficient to the initial and final measures performed by the 3 specialist observers were: The average of the initial measures by specialist 1 versus that of the specialist 2 was 0.978 and to the final averages it was 0.982 . The same correlation of the initial measures of specialist 1 versus that of specialist 3 was 0.984 and to the final measures it was 0.959 . The average of the initial measures between specialist 2 and specialist 3 was 0.979 and to the final averages it was 0.941 . thes results show a good correlation between the angles measured by the 3 specialists, with a significance level of $\mathrm{p}<0.001$. 
TABLE 1. Characterization and absolute values of LCA (in degrees) and HB graduation of all subjects at the beginning of the study and after 1 year of intervention

\begin{tabular}{|c|c|c|c|c|c|c|c|c|}
\hline $\mathrm{N}$ & Gender & Age & Cause & Side & $\begin{array}{l}\text { HB I } \\
\text { Degree }\end{array}$ & $\begin{array}{l}\text { LCA } \\
\text { Initial }\end{array}$ & $\begin{array}{l}\text { HB F } \\
\text { Degree }\end{array}$ & $\begin{array}{l}\text { LCA } \\
\text { Final }\end{array}$ \\
\hline 1 & $\mathrm{~F}$ & 45 & $\mathrm{TU}$ & $\mathrm{L}$ & IV & $104^{0}$ & IV & $92^{0}$ \\
\hline 2 & $\mathrm{~F}$ & 56 & $\mathrm{TU}$ & $\mathrm{R}$ & IV & $100^{\circ}$ & IV & $95^{0}$ \\
\hline 3 & $\mathrm{M}$ & 61 & $\mathrm{TU}$ & $\mathrm{R}$ & IV & $94^{0}$ & IV & $90^{\circ}$ \\
\hline 4 & M & 46 & $\mathrm{TU}$ & $\mathrm{L}$ & IV & $108^{0}$ & IV & $102^{0}$ \\
\hline 5 & $\mathrm{M}$ & 31 & TR & $\mathrm{L}$ & IV & $95^{0}$ & IV & $92^{0}$ \\
\hline 6 & $\mathrm{M}$ & 50 & TR & $\mathrm{L}$ & IV & $100^{\circ}$ & IV & $90^{\circ}$ \\
\hline 7 & $\mathrm{M}$ & 69 & Bell & $\mathrm{L}$ & IV & $100^{\circ}$ & IV & $90^{\circ}$ \\
\hline 8 & $\mathrm{M}$ & 43 & FFA & $\mathrm{R}$ & IV & $103^{0}$ & IV & $91^{0}$ \\
\hline 9 & $\mathrm{M}$ & 36 & $\mathrm{TU}$ & $\mathrm{L}$ & IV & $108^{0}$ & IV & $95^{0}$ \\
\hline 10 & $\mathrm{M}$ & 70 & Bell & $\mathrm{R}$ & IV & $103^{0}$ & IV & $90^{\circ}$ \\
\hline 11 & $\mathrm{~F}$ & 49 & Bell & $\mathrm{R}$ & IV & $101^{0}$ & IV & $95^{0}$ \\
\hline 12 & $\mathrm{M}$ & 22 & FFA & $\mathrm{L}$ & IV & $92^{0}$ & IV & $92^{0}$ \\
\hline 13 & M & 44 & FFA & $\mathrm{R}$ & IV & $110^{\circ}$ & IV & $100^{\circ}$ \\
\hline 14 & $\mathrm{~F}$ & 60 & $\mathrm{TU}$ & $\mathrm{R}$ & IV & $110^{0}$ & IV & $106^{0}$ \\
\hline 15 & $\mathrm{M}$ & 30 & TR & $\mathrm{L}$ & IV & $93^{0}$ & IV & $92^{0}$ \\
\hline 16 & $\mathrm{M}$ & 70 & Bell & $\mathrm{L}$ & IV & $108^{0}$ & IV & $94^{0}$ \\
\hline 17 & $\mathrm{M}$ & 30 & FFA & $\mathrm{R}$ & IV & $99^{0}$ & IV & $95^{0}$ \\
\hline 18 & $\mathrm{~F}$ & 52 & Bell & $\mathrm{R}$ & IV & $102^{0}$ & IV & $92^{0}$ \\
\hline 19 & $\mathrm{~F}$ & 42 & Bell & $\mathrm{L}$ & IV & $97^{0}$ & IV & $93^{0}$ \\
\hline 20 & M & 47 & $\mathrm{TU}$ & $\mathrm{R}$ & IV & $107^{0}$ & IV & $90^{\circ}$ \\
\hline
\end{tabular}

Legend: N: number of the subject; M: male; F: female; R: Right; L: Left ; TU: Tumor; TR: Trauma; B: Bell; FFA: Fragment of Fire Arm; HB: House \& Brackman; $\quad$ LCA: Labial Comissure Angle; I: Initial; F: Final.

\section{Discussion}

The facial muscle tonus is naturally displayed by expression lines that usually indicate the individual's chronological age and emotions. Its importance may be interpreted according to the degree of attenuation of those natural lines. The muscle tonus determines the first impact of social communication even when the face is in resting position.

Rehabilitation aims mostly to implement the tropism of the compromised muscle. It also involves the functional optimization of the residual neural fibers and the training of compensatory mechanisms. Its strategy varies according to the nature of the neural lesion, patient's age and involvement with the therapeutic process. The therapist acts as a facilitator, providing physical support and emotional rapport.

Although the facial muscle tonus is subjectively referred, its objective measurement is practically impossible. The precise measure of the PFP could be an indicator of its severity and evolution. The House-Brackmann(9) graduation, although subjective and with some restrictions, is the mostly used mean of assessment.

The assessment scales were studied while trying to determine a precise and objective, with 
quantitative computerized analysis (17-23). But they tend to be complicated, expensive and do not provide immediate result.

The need for a more adequate referential led us to consider the variation of the facial tonus as the facial aspect that is independent of the patient's interference, since it doesn't depend on his/her physical action and consequent variation or deficiency in the execution of a prompted movement. During facial rest our attention was drawn to the variation in the droop of the lip's corner according to the severity of the facial paralysis. It led us to consider the LCA the reference of this droop and therefore the indicator of favorable or unfavorable evolution of the paralysis according, respectively, to the lessening or persistence of this angle's measures. Basing the lines of this angle in static anthropometric points already recognized by the literature $(14,15,24-26)$ provided a characteristic that is common to all individuals regardless of racial, age range or gender variables.

Results in Table 1 show that there was a decrease in LCA measures in virtually all the studied subjects while the HB classification presented no changes in its graduation.

The use of electrophysiology is also being studied as a possible quantitative marker of the rehabilitation results to $\mathrm{FP}(27,28)$.

In the face with normal tonus and mobility the LCA is about: LCA=90o (Figure 2). In PFP it tends to be more obtuse (Figure 1).

Although the aim of this study wasn't to study rehabilitation per se, the studied group refers to individuals subjected to therapy according to the service's protocol. The fact that all subjects

\section{References}

1. Bernardes DF, Gomez MV, Pirana S, Bento RF. Functional profile in patients with facial paralysis treated in the myofunctional approach. Pro Fono. 2004;16(2):151-8.

2. Guedes ZCF. Atendimento fonoaudiológico das paralisias faciais no adulto e na criança. In: César CR, editor. A fonoaudiologia em instituições. São Paulo: Ed. Lovise; 1997. p.163-7.

3. Castillo-Morales R. Técnicas da terapia. In: CastilloMorales, editor. Terapia de regulação orofacial. São Paulo: Ed. Memnon; 1999. p.121-4.

4. Altmann EBC, Vaz ACN. Paralisia facial: implicações da etiologia e das diferentes cirurgias. In: Marchesan IQ, organizer. Comitê de Motricidade Orofacial da SBFa Motricidade orofacial: como atuam os especialistas. São Paulo: Ed. Pulso; 2004. p. 187-98. remained HB-IV after one year and that only the LCA presented changes in this time period points out to the muscle tone as a central feature of the rehabilitation. The reversion of hypotonicity, associated to the observed and reported functional improvement, confirms this hypothesis. The progressive adjustment in LCA, form obtuse do acute, would be an efficient indicator of either spontaneous or myofunctional improvement. The LCA value may be considered an objective data about a muscle aspect that is usually subjectively described in PFP.

Other research about orofacial rehabilitation in PFP also refer positive results according to the specific literature $(1-5,29)$. Yet, none of them presented the proposal of an objective marker for the results.

It is made clear that there is a good agreement level in the angle measurements, suggesting the reliability of the proposed measure. The results, expressed in angles, may be used to identify the evolution of each patient.

The LCA measure was the data conceived as the assessment tool about the muscle tonus in this study. The results point out to its objectivity as an assessment tool use with this purpose, besides defining whether a rehabilitation protocol to PFP is efficient or not, in a inexpensive and riskless procedure.

\section{Conclusion}

The obtained results suggest that the labial comissure angle allows the objective assessment of mo modification in facial muscle tonus.
5. Calais LL, Gomez MVSG, Benedictine Monk RF, Comerlatti LR. Avaliação funcional da mímica na paralisia facial central por acidente cerebrovascular [Mime functional evaluation in facial paralysis following a stroke]. Pro-Fono R Atual Scient. 2005;17(2):213-22.

6. de Swart BJ, Verheij JC, Beurskens CH. Problems with eating and drinking in patients with unilateral peripheral facial paralysis. Dysphagia. 2003;18(4):267-73.

7. Solomon NP. What is orofacial fatigue and how does it affect function for swallowing and speech? Semin Speech Lang. 2006;27(4):268-82.

8. Quintal M, Tessitore A, Paschoal JR, Pfeilsticker LN,. Quantificação da paralisia facial com paquímetro digital [Facial paralysis quantification by digital paquimeter]. Rev CEFAC. 2004;6(2):170-6. 
9. House JW, Brackmann DE. Facial nerve grading system. Otolaryngol Head Neck Surg. 1985;93(2):146-7.

10. Cullen RD, House JW, Brackmann DE, Luxford WM, Fisher LM. Evaluation of facial function with a questionnaire: reliability and validity. Otol Neurotol. 2007; 28:718-22.

11. Reitzen SD, Babb JS, Lalwani AK. Significance and reliability of the House-Brackmann grading system for regional facial nerve function. Otolaryngology-Head and neck Surg. 2009;140:154-158.

12. Toledo, PN. Efeito da terapia miofuncional em pacientes com paralisia facial de longa duração associada à aplicação de toxina botulínica. [tese] São Paulo:Faculdade de Medicina, Universidade de São Paulo;2007.82p.

13. Stedman Dicionário Médico. 25a. Ed. Editora Guanabara Koogan, Rio de Janeiro, 1996.

14. Silveira MC, Sígolo C, Quintal M, Sakano E, Tessitore A. Oral motricity photographic registration proposal. Rev CEFAC. 2006;8:485-492.

15. Cattoni DM. O uso do paquímetro na avaliação da morfologia orofacial [The use of the caliper in orofacial morphology evaluation]. Rev Soc Bras Fonoaudiol. 2006;11(1):52-8.

16. Cattoni DM, Fernandes FD, Di Francesco RC, Latorre Mdo R. Characteristics of the stomatognathic system of month breathing children:anthroposcopic approach. Pro Fono. 2007;19(4):347-51.

17. Tessitore A, Pfeilsticker LN, Paschoal JR. Aspectos neurofisiológicos da musculatura facial visando a reabilitação na paralisia facial. Rev CEFAC, São Paulo. 2008;10(1): 68-75.

18. Ross B, Fradet A, Nedzelski JM. Development of a sensitive clinical facial grading system. Otolaryngol Head Neck Surg. 1996;114(3):380-6.

19. Ahrens A, Skarada D, Wallace M, Cheung JY, Neely JG. Rapid, simultaneous comparison system for subjective grading scales for facial paralysis. Am J Otol. 1999;20:66771.
20. Satoh Y, Kanzanki J, Yoshihare S. A comparision and conversion table of 'the House-Brackmann Facial nerve system' and 'the Yanagihara grading system'. Auris Nasus larynx.2000;27(3):207-12.

21. Kahn JB; Gliklich RE; Boyev KP; Stewart MG; Metson RB; McKenna MJ; Bobby R. Validation of a patient-graded instrument for facial nerve paralysis: the FaCE scale. Laryngoscope. 2001;111(3):387-98.

22. Linstrom CJ. Objective facial motion analysis in patients with facial nerve disfunction. Laryngoscope. 2002;112(7Pt1):11-47.

23. Coulson SE, Croxson GR, Adams RD, O'dwyer NJ. Reliability of the [quot ]Sydney,[quot ] [quot ]Sunnybrook,[quot ] and [quot ]House Brackmann[quot ] facial grading systems to assess voluntary movement and synkinesis after facial nerve paralysis.Otolaryngol Head Neck Surg.2005;132(4):543-9.

24. Lazarini P, Mitre E, Takatu E, Tidei R. Graphic-visual adaptation of House-Brackmann facial nerve grading for peripheral facial palsy. Clin Otolaryngo. 2006 Jun;31(3):192-7.

25. Daenecke S, Bianchini EM, da Silva AP. Anthropometrical measurements of the height of the upper lip and length of the philtrum. Pro Fono. 2006; 18(3):249-58.

26. Cattoni DM, Fernandes FD. Anthropometric orofacial measurements of children from São Paulo and from North America: comparative study. Pro Fono. 2009. 21(1):25-9.

27. Rahal A, Goffi-Gomes MVS. Avaliação eletromiográfica do músculo masseter em pessoas com paralisia facial periférica de longa duração. Rev CEFAC. 2007;9(2):207-12.

28. Carvalho ARR. Preferência mastigatória em pacientes com paralisia facial periférica flácida de duração igual ou superior a seis meses: estudo clínico eletromiográfico. [tese] Faculdade de Medicina da Universidade de São Paulo; 2008. $\mathrm{p}: 117$.

29. Goffi-Gomez MVS, Vasconcelos LGE, Moraes MFBB. Trabalho miofuncional na paralisia facial. Arqu Fund Otorrinol. 1999;3(1):30-4. 